\title{
Elma Tarım Alanlarında Yüzey Toprakların Sınırlandırılmıș Su Aralığının Belirlenmesi
}

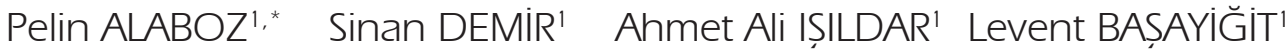 \\ 'Isparta Uygulamalı Bilimler Üniversitesi, Ziraat Fakültesi, Toprak Bilimi ve Bitki Besleme Bölümü, Isparta
}

*Sorumlu yazar e-mail (Corresponding author e-mail): pelinalaboz@isparta.edu.tr

Geliș tarihi (Received) : 12.06.2020

Kabul tarihi (Accepted): 19.10.2020

DOI: $10.21657 /$ topraksu. 752137

\section{Öz}

Son yıllarda küresel ısınmaya bağı kuraklığın artması ve su kaynaklarının azalması ile toprağa uygulanan sulama suyundan bitkinin optimum yarar sağlanması beklenmektedir. Bu kapsamda toprağın strüktür kalitesinin bir indeksi olarak bilinen sınırlandırımıș su aralığı (SSA) oldukça dikkat çekmekte ve kök gelișmesinin minimum düzeyde sınırlandıııdığı toprak su içeriği olarak tanımlanmaktadır. Bu çalıșmada; Isparta ili, Eğirdir ilçesi Boğazova çevresindeki yoğun elma üretimi yapıllan bahçelerde, yüzey toprakların SSA değerleri, dağılımları ve SSA'nın bazı toprak özellikleri ile ilișkileri araștııılıı̦tır. Çalıșmada orta-ince bünye grubu hakim olan toprakların SSA'ları \% 6.59-19.27 arasında değișim göstermiștir. Sınırlandırılmıș su aralığı özelliği; kil, organik madde ve $\mathrm{CaCO}_{3}$ ile pozitif, hacim ağırlığı ile negatif yönlü istatistiksel olarak önemli ( $\mathrm{P}<0.05 ; \mathrm{P}<0.01)$ ilișkiler sergilemiștir. Ters mesafe komșuluk benzerliği (IDW) enterpolasyon yöntemi kullanılarak olușturulan dağılım haritalarında hata kareler ortalaması karekökü \% 0.98 olarak belirlenmiștir. \% 15-20 aralıklarında SSA, çalıșma alanının güneyinde ve Eğirdir gölünün güney batısında yer alırken, \% 10-15 SSA ise genellikle kuzeyde, ağır bünyeli topraklarda belirlenmiștir. Söz konusu elma bahçelerinin \% 80'inde havalanma ve/veya sıkıșma problemleri sonucu SSA, optimum yarayıșlı su içeriklerinden daha düșük seviyelerde bulunmuștur. Çalıșma sonucunda hava dolu gözenek hacminin \% 10 olduğu nem içeriği ile tarla kapasitesi nem içeriklerinin havalanma ve sıkıșma problemlerinden oldukça fazla etkilendiği böylece SSA'nın önemli ölçüde değiștiği belirlenmiștir.

Anahtar Kelimeler: Sınırlandırılmıș su aralığı, konumsal dağı̆ım, yarayıșlı su içeriği, penetrasyon direnci

\section{Evaluation of Least Limiting Water Range of Surface Soils in Apple Agricultural Areas}

\begin{abstract}
The In recent years, it is expected that the plant obtains optimum benefit from irrigation applied to the soil since the increase of drought due to global warming and the decrease of water resources. That is why, The least limiting water range (LLWR) which is known as an index of the soil quality, draws considerable attention and is defined as the soil water content in which root development limited. In this study, LLWR values of surface soils of the orchards which intensive apple production was made in Boğazova plain, Eğirdir district Isparta province were determined. Spatial distribution of LLWR values, and relations of LLWR with some soil properties was investigated. The medium-fine texture group is dominant in the study and the SSA values of these soils varied between 6.59-19.27 $\%$. LLWR values of soils; It showed statistically positive significant relationships with clay, organic matter and $\mathrm{CaCO}_{3}$, and negative with bulk density $(\mathrm{P}<0.05 ; \mathrm{P}<0.01)$. The SSA distribution map created using the inverse distance weighting (IDW) spatial distribution method, the root mean square error (RMSE) was determined as $0.98 \%$. Soils, where LLW/R is determined between $15-20 \%$ range, are in the South
\end{abstract}


of the study area and in the southwest of Eğirdir lake. LLWR is determined between 10-15\% range, were generally determined in the North where there are fine textured soils. It was determined that 80 $\%$ of these apple orchards, LLWR values were determinde at lower levels than optimum available water capacity as a result of aeration and/or compaction problems. As a result of the study, it was determined that the moisture content of the air filled pore volume is $10 \%$ and the field capacity moisture contents are affected by the problems of aeration and compaction so that the LLWR changed significantly.

Keywords: Least limiting water range, spatial distribution, available water content, penetration resistance

\section{Gíniș}

Son yıllarda küresel ısınmaya bağı kullanılabilir su potansiyelindeki azalma, devam etmekte olan bilinçsiz su tüketimiyle birleșince özellikle kurak veyarı kurak bölgelerde su intiyaçlarının karșılanmasında sorunlara yol açmaktadır. Türkiye'de tüketilen toplam su miktarı yıllık 44 milyar $\mathrm{m}^{3}$ tür ve bu miktarın 32 milyar $\mathrm{m}^{3}$ 'ü sulamada kullanılmaktadır. Nüfus artıșı ve gelișmeye bağlı olarak 2030 yılı için kiși bașına düșen kullanılabilir su miktarının 1.120 $\mathrm{m}^{3} \mathrm{yll}^{-1}$ olarak öngörüldüğü göz önüne alındığında, su kaynaklarının kullanımı odakıı baskının artması kaçınılmazdır (Anonim, 2020). Bu nedenlerle tarımda su yönetimi, gelecekte bugün olduğundan çok daha spesifik ve özgün araștırmalara gereksinim gösteren bir konu olacaktır. Toprakta suyun daha fazla depolanması, evoporasyonun azaltılması, bitki su kullanım randımanının artıııması, bitki ıslahı ve genetik yapının değiștirilmesi gibi çalıșmalar üzerine yoğunlașılacaktır. Ancak etkin bir su yönetimi için öncelik, toprak-bitki-su ilișkilerinin iyi bilinmesi gerekmektedir.

Optimum verim için toprakta bitki besin elementlerinin yeterli düzeylerde bulunması yanında havalanma, gözeneklilik, kök penetrasyon direnci ve toprak su içeriği gibi dinamik fiziksel özelliklerin uygunluğu da gereklidir (Da Silva vd., 1994). Bitki kök bölgesindeki sıkıșmanın neden olduğu toplam gözenek miktarındaki azalma ve gözenek büyüklük dağılımındaki değișim, su ve hava kapasitesi ile hareketini etkilemektedir. Bu durumda topraktaki su içeriğinin kullanılabilirliği, toprak kütle yoğunluğundan etkilenmektedir (Zou vd., 2000; Haghighi Fashi vd., 2017). Toprağın strüktür kalitesinin bir indeksi olarak kullanılan sınırlandırılmıș su aralığı (SSA) (Leao vd., 2005), kök gelișmesinin minimum düzeyde sınırlandırılığı toprak su içeriğidir ve suyun elverișliliği, havalanma ve penetrasyon direnci gibi fiziksel değișkenleri içerir. Dolayısıyla, toprak kütle yoğunluğunun bir fonksiyonu olarak değerlendirildiğinde toprak sıkıșması doğrudan etkilidir (Keller vd., 2015).
Sınırlandırımıș su aralığı yaklașımında, kök gelișmesi üzerine etkinin üst sınır; \% 10'luk hava dolu gözenek hacmi karșilığı nem düzeyi veya tarla kapasitesi nem düzeyi, alt sınır ise solma noktası veya 2 MPa'lık penetrasyon direnci karșlığı toprak nem düzeyi olarak değerlendirilmektedir (Da Silva vd., 1994).

Toprak yönetimine bağı mekanik ve su dinamiği değișimleri SSA üzerinde etkilidir (Shaver vd. 2002). Toprak sıkıșması, SSA değerinde azalmaya yol açmakta ve dolayısıyla bitki su kullanımı olumsuz yönde etkilenmektedir (Haghighi Fashi vd., 2017; De Vares Rossetti ve Centrurion, 2017). Toprakların SSA değișim aralığının genișliği, çevresel stres altında olmadığının da bir göstergesidir (Da Silva ve Kay, 2004). Bitkinin yararlanabileceği su içeriğine yönelik belirlemeler, büyük çoğunlukla tarla kapasitesi ve solma noktası nem sabiteleri farkının alınması esasına dayalıdır (Pachepsky ve Rawls 2004; Gülser ve Candemir 2014; Mihalikova vd., 2015, Alaboz ve Ișıldar, 2018). Fakat, 2 MPa'lık toprak penetrasyon direnci karșilığı toprak nem düzeyinin solma noktası nem düzeyinden daha yüksek olması durumunda, yararlanılabilir su miktarı için yapılan söz konusu belirlemede olması gerekenden daha yüksek değerler elde edilmektedir. Benzer durum \% $10^{\prime}$ luk hava dolu gözenek hacmi karșilığı nem düzeyinin tarla kapasitesi nem düzeyinden düșük olduğu koșullar için de geçerlidir. Bu durumda bitkinin yararlanabileceği su içeriği tarla kapasitesi ve solma noktası arasındaki nem içeriği olmamaktadır.

Bitkilerin kullanabileceği su içeriğindeki sınırlama tarımsal üretimi etkilemektedir. Özellikle yarı kurak ve kurak iklimlerde ki bitkisel üretim deseninde kısıtlı olan suyun optimum yararı göz önüne alındığında yaygın olarak üretimi yapılan ürünlerde toprakbitki-su ilișkisinin ortaya konması oldukça önem arz etmektedir. Ülkemizde tarımı yaygın olarak yapılan elmanın TÜiK (2019) verilerine göre üretimi 3.618.752 ton' dur. En yüksek üretim 
potansiyeline sahip il Isparta, ilçe ise Eğirdir'dir. Elma ağaçlarında köklerin saçak yapılı ve ince köklerin nispeten yüzey derinliklerde bulunması nedeniyle su alımının yaklașık \% 70'inin $40 \mathrm{~cm}$ derinlikteki kökler vasıtasılyla gerçekleștiği belirtilmektedir (Green ve Clothier, 1999). Ayrica, maksimum kök su alımının (15 ve 28 cm) daha yüzeysel derinliklerde gerçekleștiğine ilișkin araștırma bulgularına (Andreu vd., 1997 ve Vrugt vd., 2001) ve elma bahçelerinde sürüm uygulamalarının neden olduğu kök zararlanmalarının, su ve besin elementleri alımını olumsuz yönde etkilediğine yönelik değerlendirmelere de sıkça rastlanılmaktadır. Elma ağaçlarının kökleri, toprak içerisinde yüzeysel geliștiği için sürme derinliği 12-15 cm'yi geçmemelidir (Özçağıran vd., 2011). Kültürel uygulamalara ilișkin tarla trafiği yoğunluğu, sıkıșma ve havalanma sorunlarının ortaya çıkmasına yol açabilmektedir (Ferree ve Warrington 2003). Bu çalıșmada; Isparta İli, Eğirdir ilçesi Boğazova mevkiinde yoğun elma üretimi yapılan bahçelerde, yüzey topraklarının SSA'larının belirlenmesi ve tematik harita ile dağılımlarının değerlendirilmesi yanında diğer bazı toprak özellikleri ile ilișkilerinin ortaya konması amaçlanmıștır.

\section{MATERYAL VE YÖNTEM}

\section{Çalıșma alanı}

Çalıșma alanı, Isparta-Eğirdir ilçe merkezi ve Kovada gölü arasında yer alan Boğazova vadisi Holosen yașlı alüvyonlardan olușmuștur (Karabacak 2007). Çalıșma bu Alüvyal topraklar üzerinde 2511.3 hektarlık bir alanda yürütülmüștür (Șekil 1). Karasal iklim ile Akdeniz ılıman iklimi arasında geçit bölgesinde yer alan ilde yarı kurak iklim tipi hakimdir. Bölgenin uzun yıllar meteorolojik verilerine göre yıllık ortalama sıcaklık $12.5^{\circ} \mathrm{C}$, ortalama toplam yağıș $466.8 \mathrm{~mm}$ ve evapotranspirasyon ise $724.58 \mathrm{~mm}$ dir (MGM, 2020). Elma yetiștiriciliğinin yaygın olarak yapııdığı bölge, 1970'li yıllarda Eğirdir-Kovada gölleri etkisi altında olan ve bu nedenle $V$. sınıf iken daha sonra yapay drenaj kanalları ile taban suyunun düșürüldüğü ve I. sınıf arazi kullanım kabiliyet sınıfına dönüșen alanları kapsamaktadır (Derici, 2018). Çalıșma alanını \%14'lük kısmı I. sınıf, \% 81. $5^{\prime}$ lik kısmı II. sınıf ve \% 4.5'i III. sınıf arazi kullanım kabiliyet sınıfı (AKK) içerisinde yer alan arazilerden olușmaktadır (KHGM, 1994). Çalıșmada seçilen elma bahçeleri, çöğür anacı üzerine așilı Scarlet Spur çeșidi (yarı bodur) ile kuruludur. Bahçeler ortalama 30 yașındadır.

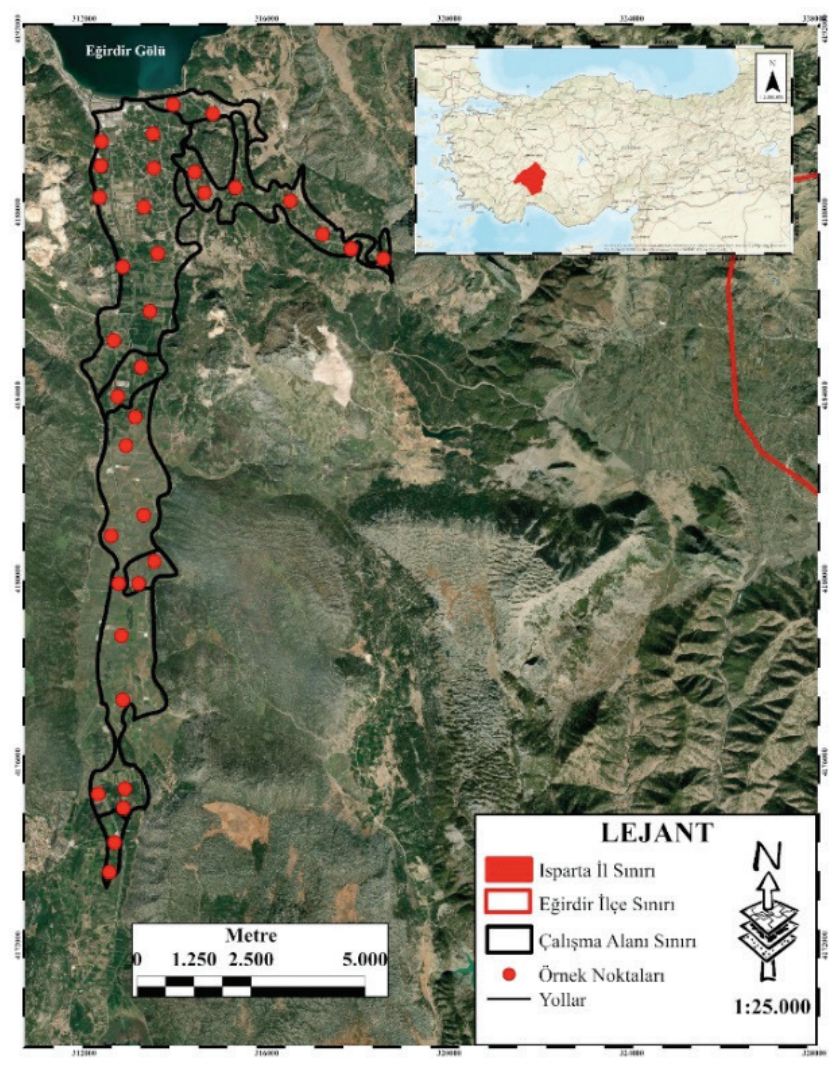

Sekil 1. Calıșma alanı

Figure 1. Study area

\section{Toprak örneklemesi ve temel toprak analizleri}

Çalıșma alanı içerisinde rastgele yöntemle 1:25.000 ölçekli Ulusal Toprak Veri Tabanı dikkate alınarak 35 noktada $0-25 \mathrm{~cm}$ derinlikten bozulmuș ve bozulmamıș yüzey toprak örneklemeleri yapıımıștır. Sınırlandırımıș su aralığı içerikleri hacim ağırlığı ve toprak sıkıșmasından etkilendiği için tarla trafiğinde en etkili sıkıșmanın yüzey toprağından olması kaynaklı bu çalıșmada $0-25 \mathrm{~cm}$ toprak derinliği ile çalıșılmıștır. Söz konusu toprak derinliklerinde penetrasyon direnci ölçümleri yapılımıș ve nem içeriği belirlemeleri için alınan örnekler yerinde tartılarak diğerleri ile birlikte laboratuvara nakledilmiștir. Bozulmuș toprak örnekleri bazı fiziksel ve kimyasal analizler için standart ön ișlemlere tabi tutulmuștur. Nem içeriğine bağlı penetrasyon direnci ve kütle yoğunluğu değișimleri için belirli aralıklarla ölçüm ve örneklemeler tekrarlanmıștır.

Toprakların mekanik analizi (\% kum, silt, kil) Bouyoucos hidrometre yöntemiyle (Bouyoucos, 1962), Kütle yoğunluğu bozulmamıș örnek alma silindirleri $\left(100 \mathrm{~cm}^{3}\right)$ kullanılarak belirlenmiștir. Toprakların elektriksel iletkenlik (EC) ve $\mathrm{pH}$ değerleri 1:1 toprak-su süspansiyonunda ölçülmüștür (Soil Survey Staff, 1992; Kacar, 2009). \% $\mathrm{CaCO}_{3}$ içeriği Volumetrik kalsimetre ve organik madde 
içeriği değiștirilmiș Walkley-Black yöntemiyle belirlenmișlerdir (Soil Survey Staff, 1992). Nem karakteristik eğrisi seramik tablalı pF seti (U.S.A, Soil Moisture Equipment Corp.) yardımıyla bozulmamıș Örneklerde hacimsel olarak belirlenmiștir (Burt, 2014).Tane yoğunluğu piknometre yöntemine göre hesaplanmıștır (Demiralay, 1993). Penetrasyon direnç (PR) ölçümleri penetrologger (Eijkelkamp) kullanılarak gerçekleștirilmiștir. Söz konusu cihaz, her bir cm için 0-10 MPa arasında ölçüm yapabilen özelliğe sahiptir. Ölçümlerde cone, 60 (NEN 5140, 1996) ve 1 cm² taban alanına sahip koni șeklinde uç kullanılmıștır.

\section{Sınırlandırılmıș su aralığı belirlemeleri}

Sınırlandırılmıș su aralığı, Wu vd. (2003) tarafından belirtilen olasılıklara göre hesaplanmıștır. Bunlar;

- $\left(\theta_{\mathrm{HG}} \geq \theta_{\mathrm{TK}}\right)$ ve $\left(\theta_{\mathrm{PR}} \leq \theta_{\mathrm{SN}}\right)$ ise $\mathbf{S S A}=\theta_{\mathrm{TK}}-\theta_{\mathrm{SN}}$

- $\left(\theta_{\mathrm{HG}} \geq \theta_{\mathrm{TK}}\right)$ ve $\left(\theta_{\mathrm{PR}} \geq \theta_{\mathrm{SN}}\right)$ ise SSA $=\theta_{\mathrm{TK}}-\theta_{\mathrm{PR}}$

- $\left(\theta_{\mathrm{HG}} \leq \theta_{\mathrm{TK}}\right)$ ve $\left(\theta_{\mathrm{PR}} \leq \theta_{\mathrm{SN}}\right)$ ise $\mathbf{S S A}=\theta_{\mathrm{HG}}-\theta_{\mathrm{SN}}$

- $\left(\theta_{\mathrm{HG}} \leq \theta_{\mathrm{TK}}\right)$ ve $\left(\theta_{\mathrm{PR}} \geq \theta_{\mathrm{SN}}\right)$ ise SSA $=\theta_{\mathrm{HG}}-\theta_{\mathrm{PR}}$

$\theta_{\mathrm{HG}}$ : Hava dolu gözenek hacminin \% 10 olduğu nem içeriği (\% v/v)

$\theta_{\text {TK }}:$ Tarla kapasitesi (\% v/v)

$\theta_{\mathrm{SN}}:$ Solma noktası (\% v/v)

$\theta_{\mathrm{PR}}:$ 2MPa penetrasyon direncinde toprak nem içeriği $(\% \mathrm{v} / \mathrm{v})$

Toprakların $\theta_{P R}$ içerikleri Busscher (1 990) tarafından belirtilen eșitlik yardımıyla belirlenmiștir (Eșitlik 1).

$P R=a \theta^{c} D_{b}^{d}$

Hava dolu gözenekliğinin \%10'a eșit olduğu

nem içeriği $\left(\theta_{\mathrm{HG}}\right)$ ise așağıdaki eșitlik yardımıyla belirlenmiștir (Eșitlik 2).

$\theta_{\mathrm{HG}}=\theta \mathrm{s}-0.10$

PR: penetrasyon direnci (MPa), $\theta$ : Hacimsel nem içeriği, $D_{b}$ : kütle yoğunluğu $\left(\mathrm{g} \mathrm{cm}^{-3}\right)$, Os: saturasyondaki su içeriği, a, c, d denklem paremetreleri olup denklem parametreleri Excel'in denklem çözücü özelliği kullanılarak belirlenmiștir.

\section{İstatistik analizler ve tematik haritalama}

İncelenen toprak özelliklerinin tanımlayıcı istatistikleri, değișkenler arasındaki ilișkinin incelendiği korelasyon analizi (Pearson), tekstür sınıfı dağılımları R studio ve Minitap 16 paket programları yardımıla değerlendirilmiștir. Noktasal verilerden konumsal veriler üretmede kullanılan enterpolasyon ișlemi așamasında ArcToolboxda Spatial Analiz Modülünde yer alan ters mesafe komșuluk benzerliği (IDW) yöntemi kullanılmıștır. Dağılım haritalarını değerlendirilmesinde hata kareler ortalaması karakök'ü (RMSE) dikkate alınmıștır (3).

$\mathrm{RMSE}=\sqrt{\frac{\sum(\mathrm{Xi}-\mathrm{X})^{2}}{\mathrm{n}}}$

Xi: tahmin değeri, X: gerçek değer, n: gözlem sayısı

\section{BULGULAR VE TARTISTMA}

\section{Toprak özelliklerine göre dağılım}

Çalıșma alanı topraklarının \%17.16'sı siltli tın (SiL), \% 31.42'si killi tın (CL), \% 17.16'sı kumlu killi tın (SCL), \% 14.27'si tın (L), \% 5.71 'i siltli kil (SiC), \% 14.28'i kil (C) bünyeye sahiptir (Șekil 2). Toprakların kütle yoğunluğu 1.12-1.62 $\mathrm{gr}_{\mathrm{cm}^{-3}}$ ve tane yoğunluğu 2.55-2.75 $\mathrm{g} \mathrm{cm}^{-3}$ aralığında değișim göstermiștir. Topraklar EC değerleri bakımından Doran ve Jones (1996)' a göre 'tuzsuz', organik madde içerikleri bakımından Hazelton ve Murphy (2016)'a göre yeterli-yüksek sınıflara girdikleri bulunmuștur. Toprakların pH'ları hafif-orta alkalin karakterde, kireç içerikleri ise Kacar (2009)'a göre ise az kireçli (\%54.28) ve çok kireçli (\% 17.15 ) sınıfları arasında belirlenmiștir. Genel toprak özelliklerine ilișkin veriler, Uçgun (2007) tarafından elde edilen bulgularla uyumludur. Toprak özelliklerinin tanımlayıcı istatistikleri çizelge 1.'de verilmiștir.

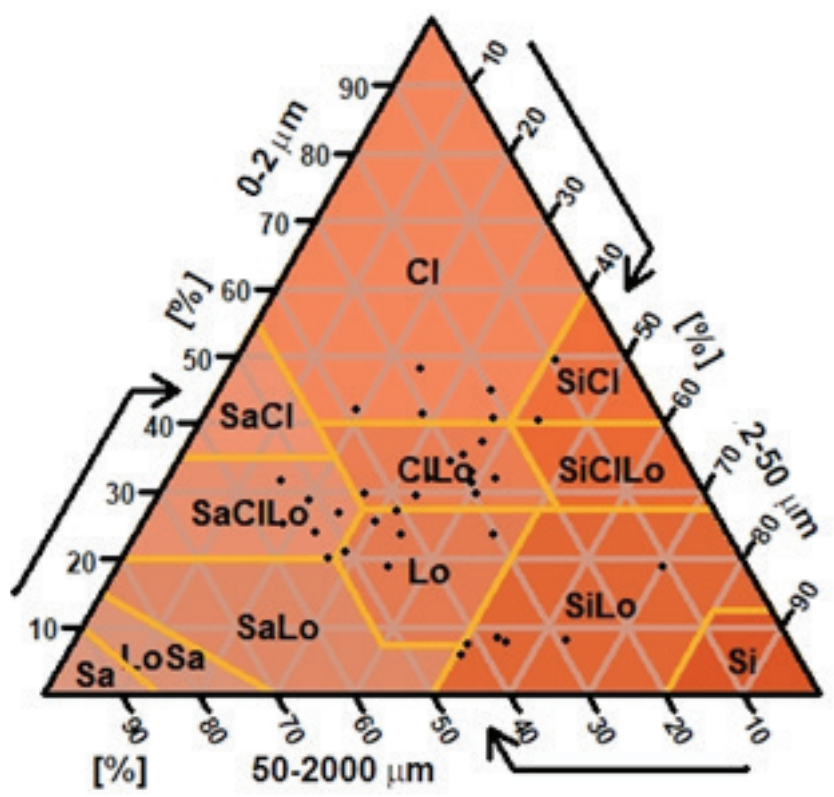

Sa:kum, Si:silt, Cl: kil, Lo:tın

Șekil 2. Tekstür sınıfı dağııımı (RStudio, 2019)

Figure 2. Texture class distribution(RStudio, 2019) 
Çizelge 1. Toprak özelliklerinin tanımlayıcı istatistikleri

Table 1. Descriptive statistics of soil properties

\begin{tabular}{lccccccc}
\hline & SS & VK & Ort & Min & Max & Crp & Bsk \\
\hline Kil $(\%)$ & 12.72 & 47.73 & 26.65 & 5.47 & 49.49 & -0.21 & -0.72 \\
Silt $(\%)$ & 13.41 & 37.43 & 35.83 & 9.93 & 70.41 & 0.49 & 0.36 \\
Kum $(\%)$ & 15.16 & 40.39 & 37.52 & 9.37 & 58.08 & 0.62 & 1.40 \\
OM $(\%)$ & 0.86 & 25.70 & 3.34 & 2.16 & 4.90 & 0.64 & -1.24 \\
$\mathrm{D}_{\mathrm{b}}\left(\mathrm{g} \mathrm{cm}^{-3}\right)$ & 0.13 & 10.06 & 11.38 & 1.12 & 1.62 & -0.21 & -0.45 \\
$\mathrm{D}_{\mathrm{p}}\left(\mathrm{g} \mathrm{cm}^{-3}\right)$ & 0.08 & 3.26 & 2.59 & 2.55 & 2.75 & 0.89 & 1.39 \\
$\mathrm{PH}$ & 0.19 & 2.38 & 8.13 & 7.68 & 8.46 & -0.22 & -1.00 \\
$\mathrm{EC}\left(\mu \mathrm{mhos} \mathrm{cm}^{-1}\right)$ & 155.8 & 38.40 & 405 & 214 & 798 & 1.39 & 1.63 \\
$\mathrm{CaCO}(\%)$ & 4.68 & 52.16 & 8.97 & 2.73 & 17.99 & -0.38 & -1.03 \\
$\theta_{\mathrm{HG}}(\%)$ & 5.54 & 14.95 & 37.12 & 27.88 & 47.02 & 0.15 & -0.57 \\
$\theta_{\mathrm{TK}}(\%)$ & 5.83 & 15.85 & 36.18 & 25.92 & 48.93 & 0.47 & 0.37 \\
$\theta_{\mathrm{SN}}(\%)$ & 4.65 & 18.09 & 25.21 & 18.33 & 35.13 & 0.41 & -0.62 \\
$\theta_{\mathrm{PR}}(\%)$ & 6.97 & 33.02 & 21.26 & 8.45 & 31.41 & -0.33 & -0.93 \\
SSA $(\%)$ & 2.94 & 24.44 & 12.03 & 6.59 & 19.27 & 0.50 & 0.22 \\
\hline
\end{tabular}

OM: organik madde, $\mathrm{D}_{\mathrm{b}}$ : hacim ağırlığı, $\mathrm{D}_{\mathrm{p}}$ : taneyoğunluğu, EC:Elektriksel iletkenlik, $\mathrm{CaCO}_{3}$ : Eșdeğer kireç içeriği, $\theta_{\mathrm{Hq}}$ : Hava dolu gözenek hacminin $\% 10$ olduğu nem içeriği , $\theta_{T K}$ : tarla kapasitesi,$\theta_{S N}$ : solma noktası, $\theta_{P R}: 2 M P a$ penetrasyon direncinde toprak nem içeriği, SSA:sınırlandırılmıș su aralığı SS:standart sapma, Ort: ortalama, Min:Minimum, Max:Maksimum VK:varyasyon katsayısı, Çrp:çarpıklık katsayısı, Bsk:basıklık katsayısı

Kay ve Anger (2002) tarafindan SSA, iyi $1>0.2$ $\left.\mathrm{cm}^{3} \mathrm{~cm}^{-3}\right)$, orta $\left(0.15-0.2 \mathrm{~cm}^{3} \mathrm{~cm}^{-3}\right)$ düșük, $(0.10-$ $\left.0.15 \mathrm{~cm}^{3} \mathrm{~cm}^{-3}\right)$ ve az $\left(<0.10 \mathrm{~cm}^{3} \mathrm{~cm}^{-3}\right)$ olarak gruplandırımaktadır. Bu kapsamda toprakların SSA değerlerinin \% 17.15'i orta, \% 60' düșük, \% 22.85'i az olarak belirlenmiștir. Genelde toprak çalıșmaları kapsamında incelenen özelliklere ilișkin varyasyon, büyük değișiklikler gösterebilmektedir. Buna neden olarak, toprak özelliğinin niteliği, niceliği, örnekleme alanı ve derinliğinin, örnekleme grubu ve diğer bazı faktörlerin değișkenliği gösterilmektedir (Bașayiğit vd., 2008; Șenol vd., 2018).

Wilding (1985)'e göre varyasyon katsayısı düșük, orta ve yüksek olarak $<\%$ 15, \%15-35, $>$ \%35) gruplara ayrılmaktadır. Bu kapsamda çalıșmada toprak reaksiyonu, $\mathrm{Db}, \theta_{\mathrm{HG}^{\prime}}$ ve $\mathrm{Dp}$ "düșük" OM, $\theta_{T K^{\prime}} \theta_{S^{\prime}} \theta_{P R}$ ve SSA "orta" kil, silt, kum, EC ve $\mathrm{CaCO}_{3}$ özellikleri ortalamaya göre "yüksek" varyasyon sergilemiștir. Wilding vd. (1994), toprakların tekstürü, rengi, derinliği gibi daha stabil olan toprak özelliklerinin diğer dinamik özelliklere göre daha dar bir aralıkta değiștiğini belirtirken Bașayiğit vd., (2008) toprak pH'sındaki değișim aralığı darlığını toprağı olușturan aktif faktörlerle ilișkilendirmiștir. Kil, $\mathrm{Db}, \mathrm{pH}, \mathrm{CaCO}_{3}$ ve $\theta_{\text {PR }}$ sola çarpık (-) diğer özelliklerde sağa çarpık $(+)$ bir dağılım göstermektedir. Çarpıklık katsayısı en yüksek normalden en uzak dağıım gösteren özellik EC olarak belirlenmiștir. Elektriksel iletkenlik özelliğinin sağa çarpık sola yığıımlı bir dağılım göstermesi toprakların EC içeriklerinin büyük bir kısmının ortalamadan (405 umhos $\mathrm{cm}^{-1}$ ) daha düșük seviyede olduğunun bir sonucudur. Söz konusu bu toprakların \% kum içerikleri diğer topraklara göre daha düșük seviyelerde belirlenmiștir. Su ve besin elementini tutma özelliği düșük olan kum fraksiyonunun toprak içerisindeki miktarının düșük seviyelerde olması tuz birikimi arttırabilmektedir. Yine bu toprakların pH seviyeleri diğer topraklara göre daha düșüktür. Bu durum düșük pH'da çözünebilir tuz miktarının artmasıyla ilișkilendirilebilmektedir (Mohd-Aizat vd., 2014; Budak vd., 2018). Silt, kum, Dp, EC ve SSA özelliklerinin eğrileri normale göre daha dik (+), diğer özellikler ise daha basık (-) olarak dağılım göstermektedir. Toprak özelliklerinin dinamik bir yapıda olması olası farklıııkların bir sebebidir

\section{Sınırlandırılmıș su aralığı ve konumsal dağılımı}

Toprakların $\theta_{\mathrm{HG}^{\prime}} \theta_{\mathrm{TK}^{\prime}}, \theta_{\mathrm{SN}}, \theta_{\mathrm{PR}}$ içerikleri sırasılyla \% $27.88-47.02$, \% 25.92-48.93, \% 18.33-35.13, \% 8.45-31.41 arasında değișmektedir. Sınırlandırıımıș su aralığı ise \% 6.59- 19.27 (v/v) seviyelerinde bulunmuștur. Sınırlandırımıș su aralığı için 
toprakların \% 40'ında $\theta_{\mathrm{TK}^{\prime}}$ ve $\%$ 60'ında $\theta_{\mathrm{HG}}$ üst sınır olarak belirlenmiștir. Alt sınırları ise \% 34.3'lük oranda $\theta_{P R}$ ve $\%$ 65.7'lik oranda $\theta_{S N}$ olusturmaktadır. Üst sınırın $\theta_{T K}$ ve alt sınırın $\theta_{S N}$ olarak gerçekleșmesi durumunda, topraklarda SSA, optimum yarayıșlı su içeriği karșılığıdır. Eğer alt sınır $\theta_{P R}$ ise daha dar bir SSA ve dolayısıyla penetrasyon direncinin yüksekliği söz konusudur.

Üst sınırın $\theta_{\mathrm{TK}}$ yerine $\theta_{\mathrm{HG}}$ olması durumu, havalanma yetersizliğinin bir göstergesidir. Sorunun sadece havalanma yetersizliği olması durumunda alt sınır değișmeksizin $\theta_{\text {sN }}$ 'dir. Alt sınır için $\theta_{\mathrm{PR}}$ durumu ise havalanma yetersizliği yanında penetrasyon direncinin yüksekliğine ișaret etmektedir. Toprakların \% 20'sinde optimum yarayıșlı su içerinin (YSI) SSA'ya eșit olduğu belirlenmiștir. Kök gelișim ve aktivitesi bakımından, penetrasyon direncinin toprakların \% 20'sinde, havalanma yetersizliğinin \% 45.7'sinde ve her ikisinin \% 14.3'ünde sınırlayıcı rol oynadığı gözlenmiștir. Yarayıșlı su içerikleri ile sınırlayıcı etkilerin hakim olduğu durumdaki SSA karșılaștırıldığında ortalama SSA değeri \% 10.91 iken bu toprakların yarayıșlı su içerikleri ortalama \% 14.15 olarak belirlenmiștir. SSA ile YSi arasındaki farkın en yüksek olduğu bazı topraklar için $1 \%$ 7.50, 5.58, 4.98, 4.93, 4.73 ) hava dolu gözenek hacminin \% 10 olduğu durumdaki nem seviyeleri (\% 36, 38, 33, 32, 30 ), tarla kapasitesindeki nem seviyesinden (\% 45, 46, 36, 37, 34) daha düșüktür. Farkın az olduğu bazı topraklar için $1 \%$ $0.64,0.86,1.82,1.96)$ ise solma noktasındaki nem içeriği $(\% 24,27,29,24) \theta_{\text {PR }}{ }^{\prime}$ den ( $\% 25$, $29,31,26)$ daha düșük seviyelerdedir. Çalıșmada SSA'nın YSi den farklı belirlenmesinde, $\theta_{\text {TK }}$ ve $\theta_{H G}$ diğer özelliklere göre daha etkili bulunmuștur. Söz konusu özellikler gözenek büyüklük dağılımından etkilenirken $\theta_{S N}$ genellikle kil içeriğiyle ilișkili olarak değișkenlik göstermektedir. Bu sebepten sıkıșma ve havalanma problemleri genellikle $\theta_{\mathrm{TK}}$ ve $\theta_{\mathrm{HG}}$ özellikleri üzerinde etki göstermektedir.

Çalıșma alanı toprakları için SSA dağılım durumu Sekil 3'de gösterilmiștir. Ters mesafe komșuluk benzerliği (IDW) enterpolasyon yöntemiyle olușturulan SSA dağılım haritalarının tahmin bașarısında hata kareler ortalaması karakökü (RMSE) değeri \% 0.98 olarak belirlenmiștir. Gerçek bir değerin modelin bu değer için öngörüsünde ne kadar saptığını belirlemek için kullanılan RMSE değerinin O'a yakın olması tahmin ile gerçek arasındaki hata payının düșük seviyelerde olduğunu göstermektedir. Sınırlandırılmıș su aralığı \% 15-20 olan toprakların, çalıșma alanının güneyinde ve Eğirdir gölünün güney batısında yer aldığı belirlenmiștir. \%10'dan küçük olan SSA ise genellikle kuzeydeki ağır bünyeli topraklarda rastlanmaktadır. Bölgede genellikle orta-ince bünye grubu hakimdir ve toprakların \% 80'inde havalanma ve/veya sıkıșma sorunları söz konusudur. Elma bahçelerinde genellikle 4 farklı dönemde toprak ișleme, 3 farklı dönemde gübreleme ve belirli aralıklarla hastalık ve zararlarla mücadele ișlemleri uygulanmaktadır (Özçağıran vd., 2011 ) Çalıșma alanındaki meyve bahçelerinde toprak ișleme, yoğun gübreleme, ilaçlama ve diğer kültüvasyon uygulamaları gibi nedenlerle; bir taraftan zayıf strüktürel durum ve bünyesel özelliğin toprakları sıkıșmaya duyarlı kılması ve diğer taraftan așırı tarla trafiğinin böyle bir tablonun ortaya çıkmasında etkili olduğu değerlendirilmektedir.

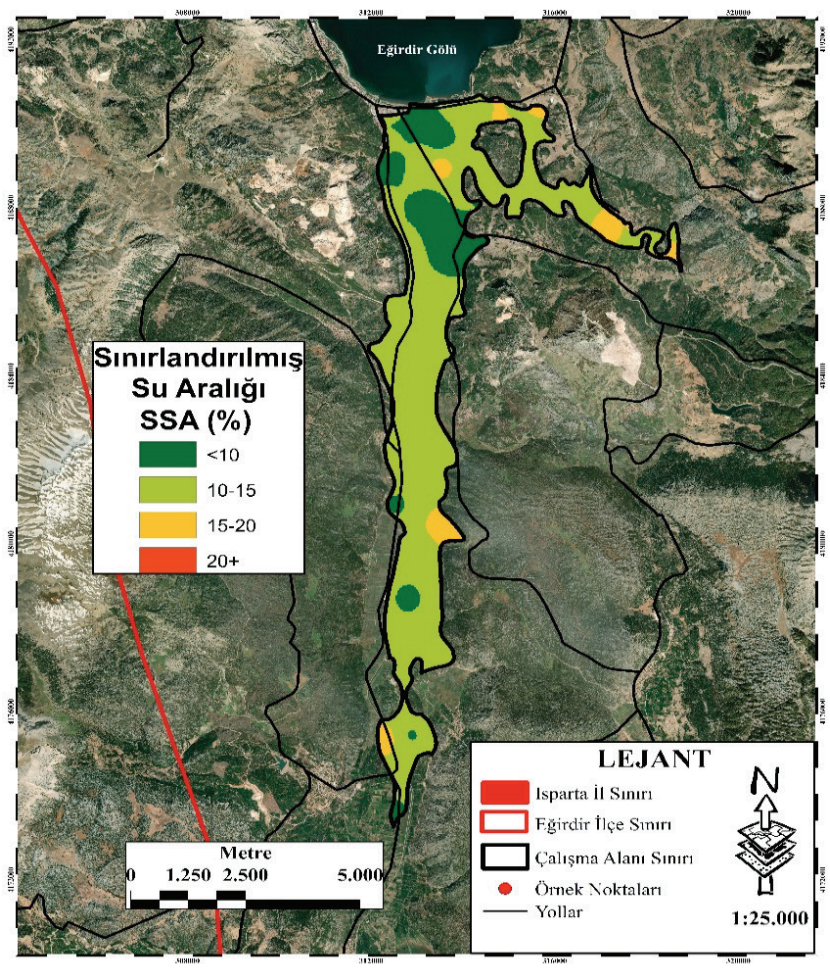

Șekil 3. Sınırlandırımıș su aralığının dağı̆ım haritası

Figure 3. Distribution map of least limiting water range

\section{Sınırlandırılmıș su aralığı ve diğer toprak özellikleri ilișkileri}

Toprak özelliklerinin korelasyon ilișkileri Cizelge 2'de belirtilmiștir. Toprak özelliklerinin korelasyon matrisleri olușturulması așamasında, çarpıklık katsayısı 0.5'den büyük olan özellikler 
için değerlerin log ve türev dönüșümleri (Șenol vd., 2018) kullanılarak normal dağııma yaklaștırımaya çalıșılmıștır. Sınırlandırılmıș su aralığı özelliği; $C, \theta_{\mathrm{HG}^{\prime}} \theta_{\mathrm{TK}^{\prime}} \theta_{\mathrm{SN}^{\prime}} \mathrm{OM}$ ve $\mathrm{CaCO}_{3}$ ile pozitif, $D_{b}$ ile negatif yönlü istatistiksel olarak önemli $(P<0.05 ; P<0.01)$ ilișkiler sergilemiștir. Toprağın su tutma özellikleri ve kil arasında pozitif yönlü ilișkilerin varlığı (Gülser, 2004, Yakupoğlu vd. 2012; Tunçay vd., 2018; Șenol vd., 2018,) geçmișten bu yana pek çok çalıșmada doğrulanmıștır. Toprağın iyi bir strüktür kazanması, agregatların dayanıklılıkları, su tutma kapasitesi, havalanması gibi fiziksel özellikleri, büyük ölçüde toprak organik maddesi ile ilgilidir (Aydemir vd., 2005). Tarla trafiğine bağlı toprak sıkıșması, kök gelișimini etkilemekte, hacim ağırlığında artıș, agregat stabilitesinde azalıșlara neden olmaktadır (Aksakal ve Öztaș, 2010). Kirec içeriğinin artmasıyla agregatlașma artmaktadır. Toprak tekstürü inceldikçe, organik madde, kireç ve suya dayanıklı agregatların miktarı arttıkça hacim ağırlığı azalmakta, gözeneklerde tutulan su miktarı artmaktadır (Yılmaz vd., 2005; Aksakal ve Öztaș, 2010). Dolayısıyla OM ve $\mathrm{CaCO}_{3}$ ile SSA arasındaki pozitif yönlü ilișkiler beklenilen bir durumdur. Organik madde sağa çarpık sola yığılımlı bir dağılım göstermektedir ve topraklar genellikle ortalamadan (\% 3.34) daha düșük değerlere sahiptir. Oysa, toprakların $\mathrm{CaCO}_{3}$ içeriklerinin büyük bir kısmı ortalamadan daha yüksek seviyelerde belirlenmiștir. $\theta_{\mathrm{HG}^{\prime}} \theta_{\mathrm{TK}^{\prime}} \theta_{\mathrm{SN}^{\prime}}$ $\theta_{\text {PR }}$ değerleri ile $\mathrm{OM}$ ve $\mathrm{CaCO}_{3}$ arasındaki ilișkiler birlikte değerlendirildiğinde $\mathrm{CaCO}_{3}$ lehine belirgin bir üstünlük olduğu gözlenmiștir (Çizelge 3). $\mathrm{CaCO}_{3}$ 'ün yüksek olduğu toprak gruplarının bazılarında kil içerikleri yüksek (\% 49.49, 48, 17 , 40.80, 40.22), organik madde içerikleri düșük olan topraklarda ise kum içerikleri yüksek $1 \%$ 58.08, 53, 19, 48.36, 40.75) seviyelerdedir. Söz konusu bu durum $\mathrm{CaCO}_{3}$ 'ün su tutma üzerine etkisini daha önemli kılmıștır.

Kütle yoğunluğu ile SSA arasında negatif yönlü önemli bir ilișki belirlenmiștir. Kütle yoğunluğunun artması diğer bir deyimle penetrasyon direnci değerinin 2 MPa'nın üzerine çıkmasıyla $\theta_{S N}$ 'nin yerini $\theta_{P R}$ aldığında, $\theta_{T K}$ 'nin aynı kaldığı koșullarda SSA'da bir daralma söz konusudur. Haghighi Fashi vd. (2017) tarafından yapılan çalıșmada kontrol koșullarında \%15 (v/v) olan SSA, sıkıșmayla birlikte \% 7(v/v) seviyelerinde belirlenmiștir. Mevcut çalıșmamızda elde edilen, kütle yoğunluğu artıșı $\theta_{\mathrm{HG}}$ 'yi azaltırken, TK ve SN'de artıșlara yol açtığına ilișkin bulgularımız, Çetin (2018) tarafından bildirilen çalıșma sonuçlarıyla uyumludur. Mikro gözeneklerde (< 0.2 mikron) tutulan su, bitkiler tarafından alınamaz. Orta gözeneklerde tutulan su ise bitkiler tarafından alınabilir. Makro gözeneklerde (> 50 mikron) ise genellikle su tutulamaz. Bu nedenle kaba gözeneklerin oranı, toprak havalanması için bir ölçü olmaktadır. Hacim ağırlığının artmasıyla makro gözenekler azalarak orta ve mikro gözeneklerde artıș gerçekleșmektedir (Cepel 1988). Yine birçok çalıșmada penetrasyon

Çizelge 2. Toprak özellikleri arasındaki pearson korelasyon katsayıları

Table 2. Pearson correlation coefficients between soil properties

\begin{tabular}{|c|c|c|c|c|c|c|c|c|c|c|}
\hline & Kil & Silt & Kum & $D_{b}$ & $\mathrm{OM}$ & $\mathrm{CaCO}_{3}$ & $\theta_{\text {TK }}$ & $\theta_{\mathrm{HG}}$ & $\theta_{S N}$ & $\theta_{P R}$ \\
\hline Kil & - & & & & & & & & & \\
\hline Silt & -0.12 & - & & & & & & & & \\
\hline Kum & $-0.75^{* *}$ & $-0.48 * *$ & - & & & & & & & \\
\hline$D_{b}$ & $-0.36 * *$ & 0.11 & 0.12 & - & & & & & & \\
\hline OM & 0.34 & $0.40 * *$ & $-0.43 * *$ & -0.10 & - & & & & & \\
\hline $\mathrm{CaCO}_{3}$ & 0.18 & -0.19 & -0.10 & $-0.30 *$ & -0.30 * & - & & & & \\
\hline$\theta_{\mathrm{TK}}$ & $0.45^{* *}$ & -0.09 & $-0.22 *$ & $0.58 * *$ & 0.23 & $0.44 * *$ & - & & & \\
\hline$\theta_{\mathrm{HG}}$ & 0.12 & 0.11 & -0.11 & $-0.60 * *$ & -0.13 & $0.21 *$ & $0.54 * *$ & - & & \\
\hline$\theta_{S N}$ & $0.41 * *$ & 0.09 & $-0.25^{*}$ & $0.45^{* *}$ & 0.20 & $0.34 *$ & $0.65 * *$ & $0.34 * *$ & - & \\
\hline$\theta_{\mathrm{PR}}$ & $0.25^{*}$ & -0.12 & -0.16 & $0.54^{* *}$ & 0.09 & $0.36 *$ & $0.47^{* *}$ & $0.48 * *$ & $0.63 * *$ & - \\
\hline SSA & $0.38^{* *}$ & -0.17 & -0.19 & $-0.43 * *$ & $0.35^{*}$ & $0.31 *$ & $0.58^{* *}$ & $0.34^{*}$ & $0.32^{*}$ & 0.20 \\
\hline
\end{tabular}


direnci ile kütle yoğunluğu arasında pozitif, nem içeriğiyle ise negatif ilișkiler gözlenmiștir (Blainski vd., 2008; Ribon ve Tavares Filho, 2008).

\section{SONUC VE ÖNERILER}

Çalıșma sonucunda toprakların büyük bir kısmının SSA'ları düșük seviyelerde belirlenmiștir. Bölgede toprakların genelinde orta-ince bünye grubu hakimdir. Özellikle uygun olmayan nem koșullarında yoğun tarla trafiği, söz konusu bünye grubu için ciddi boyutta toprak sıkıșmasına neden olmaktadır. Ayrıca uzun yıllar kapama elma tarımı yapılan bahçelerin arazi kullanımına bağlı olarak SSA'nın düșük seviyelerde belirlendiği düșünülmektedir. Toprakların \% 20'lik kısmında YSI, SSA'ya eșit belirlenirken, büyük bölümünde (\% 80) havalanma ve/veya sıkıșma problemleri tespit edilmiștir. Sınırlandırımıș su aralığının orta seviyede (\%15-20) değișim gösterdiği topraklar, çalıșma alanının güneyinde ve Eğirdir gölünün güney batısında yer alırken, düșük SSA ise genellikle kuzeyde ağır bünyeli topraklarda belirlenmiștir. Çalıșma alanının güneyi ve Eğirdir gölünün güney batısında bulunan topraklarda koruyucu toprak ișleme ve kültürel mücadele, kuzeydeki topraklarda ise tarla trafiğinin azaltılması, örtülü toprak ișleme sistemine geçilmesi yüzey toprağının strüktürel yapısının iyileștirilmesine önemli katlı sağlayacaktır. Sınırlandırımıș su aralığı $\mathrm{C}, \mathrm{OM}, \mathrm{CaCO}_{3}$ ve $\mathrm{D}_{\mathrm{b}}$ ile istatistiksel olarak önemli $(P<0.05 ; P<0.01)$ ilișkiler sergilediği korelasyon analizi sonucunda belirlenmiștir. Özellikle agregasyon ile ilișkili bu parametrelerin SSR ile önemli korelasyonlar göstermesi bu özelliklerin strüktürel yapıyı etkilemesinin bir sonucudur. Sınırlandırımıș su aralığı, YSi'den daha düșük seviyede görüldüğü topraklarda $\theta_{S N}$ ve $\theta_{P R}$ yerine $\theta_{H G}$ ve $\theta_{\text {TK }}$ özelliklerinin etkinliği daha yüksek belirlenmiștir.

Buna göre; bitkiler tarafından kullanabilir yarayıșlı su içeriğinin sıkıșmaya bağlı olarak değiștiği, SSA'nın optimum su içeriği aralığından daha düșük seviyelerde belirleneceği sonucuna varılmıștır. Bu kapsamda, özellikle bitki köklerinin sudan faydalandığı etkili kök derinliğinde ortaya çıkacak herhangi bir sıkıșma ve havalanma probleminin verim kaybına neden olacağı düșünülmektedir. Bitkinin sulamadan optimum yararı sağlayacağı koșulların elde edilebilmesi için etkili kök derinliğinde söz konusu bu özelliğin belirlenmesi önerilmektedir.

\section{KAYNAKLAR}

Aksakal EL, Öztaș T (2010). Changes in distribution patterns of soil penetration resistance within a silage-corn field following the use of heavy harvesting equipments. Turkish Journal of Agriculture and Forestry, 34: 173-179.

Alaboz P, Ișıldar AA (2018). Elma ve gül posası biyoçarlarının kumlu toprağın bazı fiziksel özellikleri üzerine etkileri. Toprak Bilimi ve Bitki Besleme Dergisi, 6(2): 67-72.

Andreu L, Hopmans JW, Schwankl U (1997). Spatial and temporal distribution of soil water balance for a dripirrigated almond tree. Agric. Water Manage, 35:123-146.

Anonim (2020). http://www.dsi.gov.tr/toprak-ve-sukaynaklari. (Erișim Tarihi: 08.06.2020)

Aydemir O, Akgül M, Canbolat MY, Ișıldar AA (2005). Toprak bilgisi. Ziraat Fakültesi Yayın No: 10, Ders Notu Yayın No: 1, Isparta, p. 172

Bașayiğit L, Șenol H, Müjdeci M (2008). Isparta ili meyve yetiștirme potansiyeli yüksek alanların bazı toprak özelliklerinin coğrafi bilgi sistemleri ile haritalanması. Süleyman Demirel Üniversitesi Ziraat Fakültesi Dergisi, $9(2): 1-10$.

Blainski É, Tormena CA, Fidalski J, Guimarães RML (2008). Quantificação da degradação física do solo por meio da curva de resistência do solo à penetração. Revista Brasileira de Ciência do Solo, 32(3): 975-983.

Bouyoucos GJ (1962). Hydrometer method improved for making particle size analyses of soils. Agron. J., 54: 464465.

Budak M, Günal H, Çelik I, Acır N, Sırrı M (2018). Dicle havzası toprak özelliklerinin yersel değișimlerinin jeoistatistik ve coğrafi bilgi sistemleri ile belirlenmesi ve haritalanması. Türkiye Tarımsal Araștırmalar Dergisi, 5(2):103-1 15.

Burt R (Ed.) (2014). Soil survey field and laboratory methods manual. United States department of agriculture, natural resources conservation service, national soil survey center, natural resources conservation service, kellog soil survey laboratory.

Busscher WJ (1990). Adjustment of flat- tipped penetrometer resistance data to a common water content. http://naldc. nal.usda. gov/download/18014/PDF. (Erișim: 08.08.20191.

Çepel N (1988). Toprak ilmi ders kitabi; orman topraklarının karakteristikleri, toprakların olușumu, özellikleri ve ekolojik bakımdan değerlendirilmesi. İstanbul Üniversitesi Orman Fakültesi Yayınları, Yayın No: 34 16, İstanbul (Çeviri), p. 276.

Çetin A (2018). Toprak nemi ve hacim ağırlığının penetrasyon direncine etkisi. Yüksek lisans tezi, Selçuk Üniversitesi Fen Bilimleri Enstütüsü (Basılmamıș), Konya.

Da Silva A, Kay B, Perfect E (1994). Characterization of the least limiting water range of soils. Soil Science Society of America Journal, 58 (6):1775-1781.

Da Silva AP, Kay BD (2004). Linking process capability analysis and least limiting water range for assessing soil physical quality. Soil and Tillage Research, 79(2):167-174. 
De Vares Rossetti K, Centurion JF (2017). Least limiting water range in Oxisols under different levels of machine traffic. Comunicata Scientiae, 8(2): 337-346.

Demiralay i (1993). Toprak fiziksel analizleri. Atatürk Üniversitesi Ziraat Fakültesi Yayınları, Erzurum, p.143.

Derici B (2018). Bütünleșik kıyı alanları yönetimi'nin (bkay) göl kıyılarında uygulanabilirliği: Eğirdir gölü örneği. Yüksek lisans tezi, Süleyman Demirel Üniversitesi, Fen Bilimleri Enstütüsü (Basılmamıș), Isparta.

Doran JW, Jones AJ (1996). Methods for assessing soil quality. Soil Science Society of America Special Publication 49. SSSA. Madison, WI., USA.

Ferree DC, Warrington IJ (Eds.) (2003). Apples: botany, production, and uses. CABI.

Green S, Clothier B (1999). The root zone dynamics of water uptake by a mature apple tree. Plant and Soil, 206(1): 61-77.

Gülser C, Candemir F (2014). Using soil moisture constants and physical properties to predict saturated hydraulic conductivity. Eurasian Journal of Soil Science, 3 77-81

Gülser C (2004). Tarla kapasitesi ve devamlı solma noktası değerlerinin toprakların fiziksel ve kimyasal özellikleriyle ilișkili pedotransfer eșitliklerle belirlenmesi. Ondokuz Mayıs üniversitesi Ziraat Fakültesi Dergisi, 19(3):19-23.

Haghighi Fashi F, Gorji M, Sharifi F (2017). Least limiting water range for different soil management practices in dryland farming in Iran. Archives of Agronomy and Soil Science, 63(13):1814-1822.

Hazelton P, Murphy B (2016). Interpreting soil test results: What do all the numbers mean?. CSIRO publishing.

Kacar B (2009). Toprak analizleri. Nobel yayın dağıtım, Ankara, p.467.

Karabacak K (2007). Eğirdir ilçesi'nin coğrafi etüdü Yüksek lisans tezi, Selçuk Üniversitesi, Sosyal Bilimler Enstitüsü, Konya.

Kay BD, Anger DA (2002). Soil structure in soil physics companion (AWarrick, Ed) 249-296.

Keller T, Da Silva AP, Tormena CA, Giarola NFB, Cavalieri KMV, Stettler M, Arvidsson J (2015). SoilFlex-SSA: linking a soil compaction model with the least limiting water range concept. Soil Use and Management, 31(2):321-329.

KHGM (1994). Köy Hizmetleri genel Müdürlüğü Isparta illi Arazi Varlığı.

Leao TP, Da Silva AP, Perfect E, Tormena CA (2005). An algorithm for calculating the least limiting water range of soils. Agronomy Journal, 97(4): 1210-1215.

Meteoroloji Genel Müdürlüğü (MGM) (2020). http:// www. mgm.gov.tr /veridegerlendirme/yillik-toplam-yagis verileri .aspx \#sfU. (Erișim tarihi: 20.01 .2020).

Mihalikova M, Bașkan O, Dengiz O (2015). Capability of different interpolation models and pedotransfer functions to estimate soil hydraulic properties in Büyükçay Watershed. Environmental Earth Sciences, 74(3): 2425-2437.
Mohd-Aizat A, Mohamad-Roslan MK, Sulaiman WNA, Karam DS (2014). The relationship between soil ph and selected soil properties in 48 years logged-over forest. International Journal of Environmental Sciences, 4(6):1129.

Özçağıran R, Ünal A, Özeker E, İsfendiyaroğlu M (2011). IIıman iklim meyve türleri. Yumușak çekirdekli meyveler Cild-II, Ege Üniversitesi Basımevi, Bornova, İzmir.

Pachepsky Y, Rawls WJ (Eds.) (2004). Development of pedotransfer functions in soil hydrology. Elsevier.

Ribon AA, Tavares Filho J (2008). Estimativa da resistência mecânica à penetração de um latossolo vermelho sob cultura perene no norte do estado do Paraná. Revista Brasileira de Ciência do Solo, 32(5): 1817-1825.

RStudio (2019) Programs download. https://rstudio.com/ products/rstudio/download/.(Erișim Tarihi:10.11.2019).

Shaver T M, Peterson GA, Ahuja LR, Westfall DG, Sherrod LA, Dunn G (2002). Surface soil physical properties after twelve years of dryland no-till management. Soil Science Society of America Journal, 66(4): 1296-1303.

Soil Survey Staff (1992). Soil survey manual. United States Department of Agronomy. Handbook No: 18. Washingto, USA.

Șenol Ș, Alaboz P, Gülsoy S, Özkan G (2018). Boylu ardıç (Juniperus excelsa Bieb.) ormanları altındaki toprakların fizikokimyasal özellikleri. Artvin Coruh Üniversitesi Orman Fakültesi Dergisi, 19(1): 1-10.

Tunçay T, Bașkan O, Bayramin I, Dengiz O, Kılıç Ș (2018). Geostatistical approach as a tool for estimation of field capacity and permanent wilting point in semiarid terrestrial ecosystem. Archives of Agronomy and Soil Science. 64 (9): 1240-1253.

Türkiye istatistik Kurumu (TÜiK) (2019). http:// www.tuik.gov.tr/UstMenu.do ?metod=temelist. (Erișim Tarihi: 10.04.2020)

Uçkun K (2007). Eğirdir-Boğazova topraklarının bazı fiziksel özelliklerinin belirlenmesi. Yüksek lisans tezi, Selçuk Üniversitesi Fen Bilimleri Enstitüsü (Basılmamıș), Konya.

Vrugt JA, Hopmans JW, Šimunek J (2001). Calibration of a two-dimensional root water uptake model. Soil Science Society of America Journal, 65(4): 1027-1037.

Wilding LP (1985). Spatial variability: Its documentation, accommodation and implication to soil surveys. 166-194p. In D.R. Nielsen and J. Bouma (eds.). Soil Spatial Variability: Pudoc. Wageningen. Netherlands.

Wilding LP, Bouma J, Goss DW (1994). Impact of Spatial Variability on Interpretative Modelling. In: Quantitative Modelling of Soil Forming Processes R.B. Bryant ve Arnold R.W. (Ed.) SSSA Special Publication Number 39, SSSA, Inc. Madison Wisconsin, USA.

Wu L, Feng G, Letey J, Ferguson L, Mitchell J, McCulloughSanden B, Markegard, G (2003). Soil management effects on the nonlimiting water range. Geoderma, 114 (3-4): 401-414.

Yakupoğlu T, Saltalı K, Karagöktaș M (2012). Narlı Ovası'nda toprak așınabilirliğinin pedotransfer yaklașım ile tahminlenmesi. Kahramanmaraș Sütçü İmam Üniversitesi Doğa Bilimleri Dergisi, 15(2):59-67. 
Yılmaz E, Alagöz Z, Öktüren F (2005). Aggregate formation and stability in soil. Selcuk Agriculture and Food Sciences Journal, 19(36):78-86 (In Turkish).
Zou C, Sands R, Buchan G, Hudson I (2000). Least limiting water range: a potential indicator of physical quality of forest soils. Soil Research, 38(5): 947-958. 